\title{
Expression and Polarization of Intercellular Adhesion Molecule-1 on Human Intestinal Epithelia: Consequences for CD11b/CD18-Mediated Interactions with Neutrophils
}

\author{
Charles A. Parkos, ${ }^{*}$ Sean P. Colgan, ${ }^{\dagger}$ Michael S. Diamond, ${ }^{\neq 1}$ \\ Asma Nusrat,* Tony W. Liang, * Timothy A. Springer, ${ }^{*}$ \\ and James L. Madara* \\ Departments of *Pathology and ${ }^{+}$Anesthesia, Division of Gastrointestinal \\ Pathology, Brigham and Women's Hospital, Boston, Massachusetts, U.S.A. \\ ${ }^{\ddagger}$ Center for Blood Research and Harvard Digestive Diseases Center, Harvard \\ Medical School, Boston, Massachusetts, U.S.A.
}

\begin{abstract}
Background: Epithelial dysfunction and patient symptoms in inflammatory intestinal diseases such as ulcerative colitis and Crohn's disease correlate with migration of neutrophils (PMN) across the intestinal epithelium. In vitro modeling of PMN transepithelial migration has revealed distinct differences from transendothelial migration. By using polarized monolayers of human intestinal epithelia (T84), PMN transepithelial migration has been shown to be dependent on the leukocyte integrin $\mathrm{CD} 1 \mathrm{lb} / \mathrm{CD} 18$ (Mac-1), but not on CD1la/CD18 (LFA1). Since intercellular adhesion molecule-1 (ICAM-1) is an important endothelial counterreceptor for these integrins, its expression in intestinal epithelia and role in PMN-intestinal epithelial interactions was investigated.

Materials and Methods: A panel of antibodies against different domains of ICAM-1, polarized monolayers of human intestinal epithelia (T84), and natural human colonic epithelia were used to examine the polarity of epithelial ICAM-1 surface expression and the functional role of ICAM-1 in neutrophil-intestinal epithelial adhesive interactions.

Results: While no surface expression of ICAM-1 was detected on unstimulated T84 cells, interferon- $\gamma$ (IFN $\gamma$ )
\end{abstract}

elicited a marked expression of ICAM-1 that selectively polarized to the apical epithelial membrane. Similarly, apically restricted surface expression of ICAM-1 was detected in natural human colonic epithelium only in association with active inflammation. With or without IFN $\gamma$ pre-exposure, physiologically directed (basolateralto-apical) transepithelial migration of PMN was unaffected by blocking monoclonal antibodies (mAbs) to ICAM-1. In contrast, PMN migration across IFN $\gamma$-stimulated monolayers in the reverse (apical-to-basolateral) direction was inhibited by anti-ICAM-1 antibodies. Adhesion studies revealed that T84 cells adhered selectively to purified $\mathrm{CD} 1 \mathrm{lb} / \mathrm{CD} 18$ and such adherence, with or without IFN $\gamma$ pre-exposure, was unaffected by ICAM-1 mAb. Similarly, freshly isolated epithelial cells from inflamed human intestine bound to CDIlb/CDI8 in an ICAM-1-independent fashion.

Conclusions: These data indicate that ICAM- 1 is strictly polarized in intestinal epithelia and does not represent a counterreceptor for neutrophil CD11b/CD18 during physiologically directed transmigration, but may facilitate apical membrane-PMN interactions after the arrival of PMN in the intestinal lumen.

\section{INTRODUCTION}

Many inflammatory diseases of mucosal surfaces are characterized by the transepithelial migration of neutrophils (PMN). For example, in active

Address correspondence and reprint requests to: Charles A. Parkos, Department of Pathology, Brigham and Women's Hospital, 75 Francis Street, Boston, MA 02115, U.S.A.

${ }^{1}$ Current address: Department of Medicine, UCSF, Box 0120, San Francisco, CA 94143, U.S.A. ulcerative colitis and Crohn's disease, migration of PMN across the intestinal epithelial lining results in the classic histological feature of the crypt abscess $(1,2)$. Using model intestinal epithelia, we have previously shown that specific interactions occurring between PMN and intestinal epithelia during transmigration can influence crucial epithelial functions ranging from barrier maintenance to electrolyte secretion (3-8). Sim- 
ilar relationships between PMN-epithelial interactions and epithelial dysfunction likely also occur in the human intestine, since transepithelial PMN migration correlates well with barrier perturbation and symptomatology in patients with inflammatory bowel disease (9).

Perhaps the best-characterized paradigm for migration of PMN across cell monolayers is migration across vascular endothelium. However, it is likely that migration across endothelia differs substantially from that across polarized columnar epithelia. For example, the initial adhesive interaction between PMN and endothelium occurs under conditions of vascular shear and is regulated by lectin-like molecules termed selectins (10). Shear flow is not encountered during transepithelial migration. Moreover, the geometry of PMN interactions with endothelia and columnar epithelia differs considerably. In the vasculature, initial interactions with PMN occur at the endothelial apical surface, while initial interactions of PMN with epithelia occur at the epithelial basolateral surface. In contrast to relatively flat endothelial cells, columnar epithelial cells are often $>20 \mu$ in height, likely dictating extensive interactions with the lateral membrane during the process of PMN transepithelial migration. For example, lateral epithelial membrane interactions with PMN are mediated by CD47 (11), events which occur after CD1 lb/CD18-mediated adhesion. PMN also appear to use distinct repertoires of leukocyte integrins to cross endothelial and epithelial barriers. PMN adhesion to endothelial cells can be inhibited by monoclonal antibodies (mAbs) against CD1la/CD18 (leukocyte function-associated antigen; LFA-1) $(12,13)$, and against CDllb/CD18 (Mac-1, Mol) $(12,14,15)$. In contrast, physiologically directed (basolateralto-apical) transepithelial migration appears to be mediated exclusively by CD1 lb/CD18 (16). Additionally, while lectin-like adhesive interactions occur between PMN and epithelia, they are distinct from the selectin-mediated adhesive events characterizing PMN-endothelial interactions (17). Lastly, whereas transendothelial migration of PMN is modulated by the cytokines interleukin 1 (IL-1) and tumor necrosis factor (TNF) and by lipopolysaccharide (LPS) (15), these agents have no effect on PMN migration into, or across, epithelial monolayers (18). However, stimulation of epithelia with interferon- $\gamma($ IFN $\gamma$ ), a dominant cytokine of the intestinal mucosa $(19,20)$, modulates $n$-formylated peptide (fMLP)-driven transepithelial migration of PMN via $\mathrm{CD} / \mathrm{lb} /$ CDl8-dependent mechanisms (18). Enhanced intercellular adhesion molecule-1 (ICAM-1) expression at the vascular surface of endothelial cells in states of inflammation is important for both CD11b/CD18-and CD1 la/CD18-mediated firm adhesion. The regions on ICAM- 1 that interact with the CD1la/CD18 and CD11b/CD18 integrins have been characterized and mapped to domains 1 and 3 , respectively $(21,22)$. However, the potential role of ICAM- 1 in PMN interactions with columnar epithelia is much less clear. $\mathrm{Nu}$ merous studies report epithelial cell ICAM-1 expression (23-29) and thus, it is often assumed that ICAM-1 plays a crucial role in epithelialPMN interactions. However, the distribution of ICAM-1 on the surface of polarized epithelial cells has not been unequivocally defined. In addition, there are no reports detailing the role of ICAM-1 in mediating PMN-epithelial interactions during physiologically directed (basolateral-to-apical) transepithelial migration. Lastly, it is not known whether ICAM-1 on epithelia indeed serves as a major ligand for CD11b/CD18mediated adherence.

In this study, we show that ICAM-1 is inducible in T84 intestinal epithelial cells and that ICAM-1 similarly appears focally on inflamed human intestinal epithelium in vivo. In both settings, ICAM-1 surface expression is restricted to the apical membrane domain. fMLP-driven transepithelial migration of PMN is attenuated by antibodies to ICAM-1 only when the direction of migration is apical-to-basolateral (nonphysiologic) thus affording PMN access to apically restricted ICAM-1. These antibodies do not block PMN transmigration in the physiologic direction, adhesion of suspended T84 cells to immobilized, purified $\mathrm{CD} 1 \mathrm{lb} / \mathrm{CD} 18$, or adhesion of freshly isolated epithelial cells from inflamed intestine to purified CD11b/CD18. Thus, ICAM-1 interactions with the PMN integrin CD $1 \mathrm{lb} / \mathrm{CD} 18$ play no role in physiologically directed transmigration of PMN, indicating that novel epithelial counterreceptors for $\mathrm{CD} 1 \mathrm{lb} / \mathrm{CD} 18$ must exist on the basolateral membrane. The apical polarization of ICAM-1 together with data indicating that ICAM-1 can mediate interactions with PMN once they appear in the lumen, suggest that ICAM-1 may mediate post-transmigration interactions between PMN and epithelial apical membranes.

\section{MATERIALS AND METHODS Cell Culture}

Monolayers of the human intestinal epithelial cell line T84 (30) were used to study ICAM-1 
localization on intestinal epithelia and the functional role of ICAM-1 in epithelial-neutrophil interactions in vitro. T84 cells were grown in a 1:1 mixture of Dulbecco's modified Eagle's medium and Hams F-12 medium supplemented with $15 \mathrm{mM}$ HEPES buffer ( $\mathrm{pH} 7.5$ ), $14 \mathrm{mM}$ $\mathrm{NaHCO}_{3}, 40 \mu \mathrm{g} / \mathrm{ml}$ penicillin, $8 \mu \mathrm{g} / \mathrm{ml}$ ampicillin, $90 \mu \mathrm{g} / \mathrm{ml}$ streptomycin, and 5\% newborn calf serum. Subculturing (or harvesting) was performed every 6-8 days by treatment with $0.1 \%$ trypsin and $1.0 \mathrm{mM}$ EDTA in $\mathrm{Ca}^{++}$- and $\mathrm{Mg}^{++}$. free phosphate-buffered saline (30). For apicalto-basolateral transmigration experiments, T84 cells were grown on collagen-coated, polycarbonate permeable supports (inserts) with a surface area of $0.33 \mathrm{~cm}^{2}$ (Costar Inc., Cambridge, MA, U.S.A.) as previously described (16,31). For physiologically directed (basolateral-to-apical) transmigration assays, T84 cells were plated on the underside of collagen-coated permeable filters resulting in inverted monolayers (16). Such inverted monolayers allow gravitational settling of PMN onto the filter and, subsequently, contact with the basolateral aspect of the monolayer. For surface-labeling experiments by ELISA, T84 cells were plated at 3/4 confluent density in 96-well microtiter plates and used 2-3 days later. Suspended T84 cells for use in adhesion or surfacelabeling experiments were prepared by standard trypsin/EDTA (31) treatment of monolayers grown on plastic.

Transfected L cells expressing surface ICAM-1 were maintained in DME supplemented with $100 \mu \mathrm{M}$ hypoxanthine, $400 \mathrm{nM}$ aminopterin, and $16 \mu \mathrm{M}$ thymidine as previously described (14). CHO cell transfectants expressing a glycosyl-phosphatidylinositol anchored form of human ICAM-1 (GPI-ICAM-1) or a domain-deleted form of ICAM-1 (F185-ICAM-1) were grown and maintained as described previously $(32,33)$. As shown in the past, F185-ICAM-1 lacks domain 3 of ICAM-1, whereas GPIICAM-1 contains all five domains.

\section{Isolation of Human Intestinal Epithelial Cells}

Primary isolates of human colonic epithelial cells were obtained immediately following surgical resection of colonic segments containing normal mucosa or mucosa involved by medically refractory inflammatory bowel disease. Normal colonic epithelial cells were obtained from uninvolved mucosa of colon specimens resected for therapy of colonic adenocarcinoma. Using a procedure extensively modified from (34), approximately five $10-\mathrm{cm}^{2}$ sections of mucosa were washed in RPMI media followed by incubation in RPMI containing $1.5 \mathrm{mM}$ dithiothreitol (DTT) (BioRad Inc., Richmond, CA, U.S.A.) and 2 mM EDTA for $20 \mathrm{~min}$. After a second incubation for $20 \mathrm{~min}$. in the same buffer without DTT, epithelial cells were dislodged by gentle scraping of the mucosa with fine-mesh stainless steel screen and used as epithelial cell suspensions.

\section{Neutrophil Isolation}

Neutrophils (PMN) were isolated from whole blood (anticoagulated with citrate/dextrose) obtained from normal human volunteers, using a gelatin sedimentation technique as previously described in detail (35). PMN were resuspended in modified $\mathrm{HBSS}$ without $\mathrm{Ca}^{++}$and $\mathrm{Mg}^{++}$ (HBSS [-]) at a concentration of $4 \times 10^{7} \mathrm{cells} / \mathrm{ml}$ $\left(4^{\circ} \mathrm{C}\right)$ and used for subsequent experiments.

\section{Antibodies}

Antibodies to ICAM-1 (Table 1) included the previously characterized R6.5 (IgG2a) $(12,14,21)$ and RR1/1 (IgG 1) (36,37). Binding, noninhibitory antibody controls included mAb to major histocompatibility complex (MHC 1), W6/32 (38), anti-CDlla/CD18 (mAb TSl/22 [39]) and anti-CD1 lb/CD18 (mAb OKMl [40]). Inhibition of CD l lb-dependent binding was achieved using either mAb 44a $(16,41)$ or mAb CBRMl/29 (33).

Additional mAbs to human ICAM-1 that were used were generated by previously described methods $(33,42)$. In brief, female BALB/c mice were immunized with purified ICAM-1 (2 $\mu \mathrm{g} /$ immunization) (43) 28 days (intraperitoneally) and 3 days (intraperitoneally and intravenously) before fusion of splenocytes with the nonsecreting murine myeloma P3X63Ag8.653 (CRL 1580; American Type Culture Collection, Rockville, MD, U.S.A.). To select for mAb to ICAM-1, indirect immunofluorescence flow cytometry was used. ICAM-1 mAbs that blocked binding to Mac-1 but not to LFA-1 were identified by selecting hybridomas that preferentially recognized domain 3 of ICAM-1. Hybridomas $(n=672)$ were screened against $\mathrm{CHO}$ cell transfectants expressing a glycosyl-phosphatidylinositol-anchored form of human ICAM-1 (GPIICAM-1) (32) or a domain-deleted form of ICAM-1 (F185-ICAM-1) (14). All five domains of ICAM- 1 are present on GPI-ICAM-1, whereas domain 3 is deleted on F185-ICAM-1. To permit 
TABLE 1. Functional specificities of anti-ICAM-1 mAbs

\begin{tabular}{|c|c|c|c|}
\hline $\mathbf{m A b}$ & Isotype & $\begin{array}{l}\text { Inhibition of Binding to } \\
\text { Purified CD } 11 \mathrm{~b} / \mathrm{CD} 18^{a}\end{array}$ & $\begin{array}{l}\text { Inhibition of Binding to } \\
\text { Purified CD } 11 \text { a/CD } 18^{b}\end{array}$ \\
\hline $\mathrm{RR} 1 / \mathrm{l}$ & IgG 1 & - & +++ \\
\hline R6.5 & $\operatorname{IgG} 2 a$ & +++ & ++++ \\
\hline CBRICl/7 & IgG 1 & ++++ & ++ \\
\hline CBRIC $1 / 11$ & IgGl & ++++ & + \\
\hline CBRIC $1 / 12$ & $\operatorname{IgG1}$ & - & - \\
\hline
\end{tabular}

simultaneous screening, the two CHO transfectants were differentially labeled. GPI-ICAM-1expressing $\mathrm{CHO}$ cells were labeled red with $10 \mathrm{ml}$ of a filtered solution that contained the DNAintercalating dye hydroethidine $(40 \mu \mathrm{g} / \mathrm{ml}$; Polysciences Inc., Warrington, PA, U.S.A.) and DME, $5 \% \mathrm{FCS}$ for $30 \mathrm{~min}$ at $37^{\circ} \mathrm{C}(14)$. Excess dye was removed by washing four times with DME, $5 \%$ FCS. In contrast, F185-ICAM-1-expressing CHO cells were not labeled. Subsequently, $\mathrm{CHO}$ transfectants $\left(2.5 \times 10^{4}\right.$ of each population) were mixed, incubated in microtiter plates with hybridoma supernatants, labeled with FITC-conjugated secondary antibodies, and subjected to flow cytometry. Of 275 hybridomas that recognized the GPI-ICAM-1 expressing CHO cells, 15 did not recognize the F185-ICAM-1 CHO cells. Three of these mAbs, CBRIC1/7, CBRIC1/11, and CBRICl/12 (IgGl isotype) (44), are characterized here. Hybridomas were cloned twice by limiting dilution, isotyped (Immunopure mAb Isotyping Kit, Pierce, Rockford, IL, U.S.A.), and antibody purity was confirmed by reducing ( $5 \%$ $\beta$-mercaptoethanol) and nonreducing $(50 \mathrm{mM}$ iodoacetamide) SDS-8\% PAGE.

\section{Protein Purification}

Mac- 1 and LFA-1 were purified by immunoaffinity chromatography using peripheral blood leukocyte lysates as previously described $(14,45)$. ICAM-1 was purified by immunoaffinity chromatography from detergent lysates of the erythroleukemic cell line K562 as described (43).

\section{Antibody Labeling/Immunoprecipitation Experiments}

To determine surface expression of ICAM-1, a combination of cell surface ELISA, immunofluorescence and biotinylation/immunoprecipitation techniques were used. Crude surface expression of ICAM-1 was assayed by ELISA. Briefly, T84 cell suspensions were treated with human recombinant IFN $\gamma$ (generously provided by Genentech, $1000 \mathrm{U} / \mathrm{ml}$ ) as previously reported (18), plated at $75 \%$ confluent density and cultured for $48 \mathrm{hr}$. To assay surface expression of ICAM-1, monolayers were washed with HBSS (HBSS (in $\mathrm{g} / \mathrm{l}): \mathrm{CaCl}_{2} 0.185, \mathrm{MgSO}_{4} 0.098, \mathrm{KCl} \mathrm{0.4}, \mathrm{KH}_{2} \mathrm{PO}_{4}$ $0.06, \mathrm{NaCl} 8, \mathrm{Na}_{2} \mathrm{HPO}_{4} 0.048$, glucose 1 , and HEPES added to $10 \mathrm{mM}, \mathrm{pH} 7.4$ ), cooled to $4^{\circ} \mathrm{C}$ and incubated with anti-ICAM-1 for $2 \mathrm{hr}$. After washing and incubation with peroxidase-conjugated secondary antibody $\left(1 \mathrm{hr}, 4^{\circ} \mathrm{C}\right)$, color development with ABTS (2,2'Azino-bis(3-ethylbenzthiazoline-6-sulfonic acid) (Sigma Chemical Co., St Louis, MO, U.S.A.) was performed. Antibody binding was quantitated at OD 405 using a microtiter plate reader as previously described (46). The above ELISA was modified and used to assess sensitivity of ICAM-1 epitopes to cell trypsinization procedures. In such experiments, T84 cells were plated in the absence (media alone) or presence of IFN $\gamma(1000 \mathrm{U} / \mathrm{ml})$ on 25 $\mathrm{cm}^{2}$ tissue culture flasks. After $48 \mathrm{hr}$, the cells were harvested using standard trypsinization techniques as described above. The washed cell pellets were divided into equal aliquots of $15 \mathrm{~cm}^{2}$ 
$\left(\sim 1.5 \times 10^{7}\right.$ cells $)$ in microcentrifuge tubes, cooled to $4^{\circ} \mathrm{C}$, and incubated for $2 \mathrm{hr}$ with 10 $\mu \mathrm{g} / \mathrm{ml}$ anti-ICAM- 1 . The cells were pelleted, washed, and incubated at $4^{\circ} \mathrm{C}$ with peroxidaseconjugated secondary antibody for $1 \mathrm{hr}$. After washing, color was developed with ABTS and the cell-free supernatant assayed at OD405 as described above.

Immunoprecipitation experiments were performed on T84 monolayers selectively biotinylated on the apical or basolateral surface $(47,48)$. T84 monolayers cultured on $5-\mathrm{cm}^{2}$ permeable supports were washed free of media and selectively labeled on the apical or basolateral surface with a solution of $1 \mathrm{mM}$ sulfo-NHS biotin (Pierce) in HBSS for $20 \min \left(4^{\circ} \mathrm{C}\right)$. The biotinylation reaction was quenched with $150 \mathrm{mM}$ $\mathrm{NH}_{4} \mathrm{Cl}$, and each $5-\mathrm{cm}^{2}$ monolayer was solubilized in $1 \mathrm{ml}$ of buffer containing $100 \mathrm{mM} \mathrm{KCl}$, $30 \mathrm{mM} \mathrm{NaCl}, 2 \mathrm{mM}$ EDTA, $10 \mathrm{mM}$ HEPES, $\mathrm{pH}$ $7.4,2 \%$ Triton $X-100$, and protease inhibitors including $1.25 \mathrm{mM}$ PMSF, $5 \mu \mathrm{g} / \mathrm{ml}$ chymostatin, $1 \mu \mathrm{g} / \mathrm{ml}$ each of leupeptin, pepstatin, and bestatin $\left(4^{\circ} \mathrm{C}\right)$. The T84 cell lysate was precleared for 2 hr with $50 \mu \mathrm{l}$ of IgG-Sepharose (normal mouse IgG coupled to CNBR activated Sepharose $6 \mathrm{MB}$ at a protein/sepharose ratio of $3 \mathrm{mg} / \mathrm{ml}$ according to the manufacturer's instructions (Pharmacia Inc., Upsala, Sweden) followed by incubation for $2 \mathrm{hr}$ with $20 \mu \mathrm{l}$ anti-ICAM-1-Sepharose (R6.5), prepared as above $\left(4^{\circ} \mathrm{C}\right)$. The washed immunoprecipitates were denatured by heating to $100^{\circ} \mathrm{C}$ in the presence of $50 \mu \mathrm{l}$ of nonreduced sample buffer followed by reduced SDS-PAGE and Western blotting using standard protocols. Labeled proteins were visualized after incubation with peroxidase-conjugated streptavidin using enhanced chemiluminescence, according to the manufacturer's instructions (Amersham).

For immunofluorescence, T84 monolayers were fixed in $3.7 \%$ paraformaldehyde in PBS (20 $\min , 20^{\circ} \mathrm{C}$ ) and washed with gelatin-PBS. Fixed monolayers were then permeabilized with PBS containing $0.5 \%$ Triton X-100 $\left(15 \mathrm{~min}, 20^{\circ} \mathrm{C}\right)$ followed by incubation with $10 \mu \mathrm{g} / \mathrm{ml} 1^{\circ}$ antibody diluted in gelatin-PBS $\left(2 \mathrm{hr}, 20^{\circ} \mathrm{C}\right)$. After washing, monolayers were incubated with FITCconjugated $2^{\circ}$ antibody ( 1 hour, $20^{\circ} \mathrm{C}$; Cappel Inc., Durham, NC, U.S.A.) and mounted in PBSglycerol- $p$-phenylenediamine. Labeled monolayers were then viewed with a Zeiss/BioRad MRC600 confocal fluorescence microscope. As a control for background labeling, control monolayers were incubated with comparable concentrations of normal mouse IgG. As a positive con- trol for basolateral labeling, anti- $\beta 1$ integrin was used (Telios Inc., San Diego, CA, U.S.A.).

\section{Immunostaining of Human Tissue}

ICAM- 1 staining was also performed on $3 \mu$ frozen tissue sections of human colonic mucosa obtained from fresh surgical specimens. Tissue sections, mounted on glass coverslips, were air dried followed by fixation in $3.7 \%$ paraformaldehyde as above. Fluorescent labeling was performed as above.

\section{Transmigration Experiments}

FMLP-driven PMN transmigration experiments were performed using both standard (apical-tobasolateral migration) and inverted (basolateralto-apical migration) T84 monolayers as previously described (16,31). Briefly, confluent T84 monolayers were washed free of media and preincubated with saturating concentrations of antibody $\left(20 \mathrm{~min}, 20^{\circ} \mathrm{C}\right)$. For such antibody preincubation, $50 \mu$ l of antibody in HBSS was added to the upper chamber of the monolayer setup. After a 20-min preincubation, HBSS was added $(100 \mu \mathrm{l})$ followed by $1 \times 10^{6} \mathrm{PMN}$ in $25 \mu \mathrm{l}$ HBSS (-) (HBSS as above but without $\mathrm{CaCl}_{2}$ or $\left.\mathrm{MgSO}_{4}\right)$. Transmigration was initiated by transfer of antibody/PMN containing monolayers to 24well tissue culture plates containing $1 \mathrm{ml}$ of $1 \mu \mathrm{M}$ fMLP in HBSS. After incubation for $110 \mathrm{~min}$ at $37^{\circ} \mathrm{C}$, neutrophil migration across monolayers to the fMLP-containing lower chambers was quantitated by myeloperoxidase assay (16). Migration across monolayers pretreated with IFN $\gamma$ (1000 $\mathrm{U} / \mathrm{ml}, 48 \mathrm{hr}$ ) was compared with that across control, untreated monolayers.

\section{Adhesion Experiments}

The effects of anti-ICAM-1 antibodies on intestinal epithelial cell binding to $\mathrm{CD} 1 \mathrm{lb} / \mathrm{CD} 18$ was assayed using a slightly modified form of a previously described method (14). Microtiter plates were coated with functionally active purified $\mathrm{CD} 1 \mathrm{lb} / \mathrm{CD} 18$. For optimal coating with $\mathrm{CD} 1 \mathrm{lb} /$ $\mathrm{CD} 18$, a solution of purified integrin at $\geq 0.1$ $\mathrm{mg} / \mathrm{ml}$ was diluted 15 -fold with $150 \mathrm{mM} \mathrm{NaCl}, 2$ $\mathrm{mM} \mathrm{MgCl}$, and $25 \mathrm{mM}$ Tris, $\mathrm{pH}$ 7.3, and allowed to bind to microtiter wells for $2 \mathrm{hr}\left(20^{\circ} \mathrm{C}\right)$. Nonspecific binding was blocked by incubation with a solution of blocking buffer containing $0.5 \%$ bovine serum albumin (phosphate-buffered saline, $\mathrm{pH} 7.4$, containing $2 \mathrm{mM} \mathrm{MgCl}_{2}, 10 \mathrm{mM}$ 
dextrose, and $0.5 \%$ BSA). T84 cells and human colonocytes were resuspended in blocking buffer and fluorescently labeled for $10 \mathrm{~min}$ at $37^{\circ} \mathrm{C}$ by incubation with $5 \mu \mathrm{g} / \mathrm{ml}$ BCECF-AM $\left(2^{\prime}, 7^{\prime}\right.$ bis(2-carboxyethyl)-5-(and-6)-carboxyfluorescein acetoxymethyl ester; Molecular Probes Inc., Eugene, OR, U.S.A.), washed and immediately used in adhesion assays. Antibodies in blocking buffer were added to the CDI1b/CD18-coated microtiter plates followed by a 20 -min incubation $\left(20^{\circ} \mathrm{C}\right)$. Subsequently, labeled epithelial cells $(50$ $\mu \mathrm{l}, \sim 2.5 \times 10^{5}$ cells per well) were added, followed by gentle, constant swirling for $15 \mathrm{~min}$ to allow antibody binding to cells while preventing adhesion $\left(20^{\circ} \mathrm{C}\right)$. Plates were then held flat and stationary at $37^{\circ} \mathrm{C}$ for $1 \mathrm{hr}$ to permit adhesion. To quantitate adhesion, each well was gently washed twice, and total fluorescence of each well was assayed at an excitation/emission wavelength of $485 / 535 \mathrm{~nm}$ using a fluorescence microtiter plate reader (Millipore Inc., Milford, MA, U.S.A.). The percentage of applied cells adherent to purified $\mathrm{CD} 1 \mathrm{lb} / \mathrm{CD} 18$ in the absence of inhibition typically ranged from 25 to $55 \%$. Adhesion was calculated as the fluorescence ratio (postwash fluorescence/prewash fluorescence) $\times 100$ and expressed as the percentage of adherent cells.

The binding of ICAM-1-transfected (ICAM$\mathrm{1}^{+}$) L cells was examined as previously detailed (14). Briefly, purified CDIlb/CD18 and CDlla/ $\mathrm{CD} 18$ were diluted and absorbed $(25 \mu \mathrm{l})$ to $6-\mathrm{cm}$ petri dishes for $50 \mathrm{~min}$ at $37^{\circ} \mathrm{C}$, and nonspecific sites were blocked by subsequent addition of PBS, $2 \mathrm{mM} \mathrm{MgCl}_{2}, 0.5 \%$ heat-treated BSA (blocking buffer). After removal from tissue culture plates with trypsin-EDTA (Gibco Laboratories, Grand Island, NY, U.S.A.), ICAM- $1^{+}$L cells were washed twice and resuspended in PBS, 2 $\mathrm{mM} \mathrm{MgCl}_{2}, 0.5 \%$ heat-treated BSA $\left(5.0 \times 10^{6}\right.$ cells $/ \mathrm{ml}$ ). For $30 \mathrm{~min}$ prior to the binding assay, cells $\left(1.0 \times 10^{6}\right.$ cells in $\left.200 \mu \mathrm{l}\right)$ were preincubated at $4^{\circ} \mathrm{C}$ with mAb $(200 \mu \mathrm{l}$ of culture supernatant or $20 \mu \mathrm{g} / \mathrm{ml}$ purified mAb). Subsequently, cells were washed once and resuspended $(1.0 \times$ $10^{6}$ cells $/ \mathrm{ml}$ ) in blocking buffer, added in $1 \mathrm{ml}$ to petri dishes, and incubated for $50 \mathrm{~min}$ at $37^{\circ} \mathrm{C}$. The procedure for washing and quantitation of adhesion has been described (14).

\section{Statistical Analysis}

Data are presented as the mean \pm SD and compared by Student's $t$ test or by one-way analysis of variance (ANOVA).

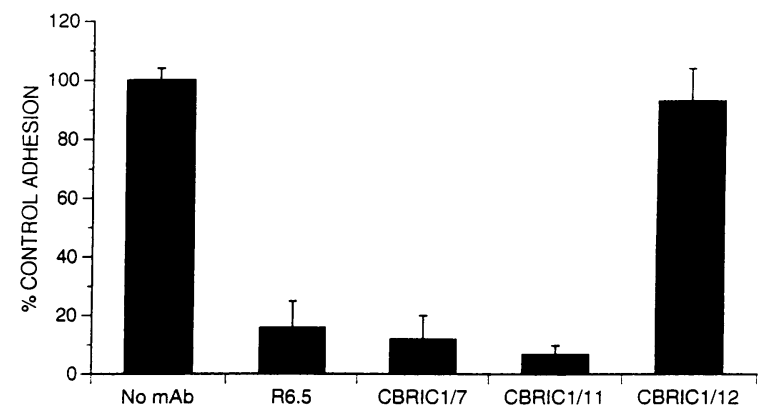

FIG. 1. Effect of mAbs on adhesion of ICAM-1 transfected $L$ cells to purified $C D 11$ b/CD18

ICAM-1-expressing L cells were detached, washed, and resuspended $\left(5 \times 10^{6} / \mathrm{ml}\right)$ in PBS containing 2 $\mathrm{mM} \mathrm{MgCl}$ and $2 \%$ heat-treated BSA as described in Materials and Methods. Cells were preincubated for 30 min with no antibody (No mAb) or with one of the anti-ICAM- $1 \mathrm{mAb}$ above $\left(20 \mu \mathrm{g} / \mathrm{ml}, 4^{\circ} \mathrm{C}\right)$. Subsequently, cells were washed, resuspended $\left(10^{6} / \mathrm{ml}\right)$, and allowed to bind to $6-\mathrm{cm}$ petri dishes coated with purified $\mathrm{CD} 1 \mathrm{lb} / \mathrm{CD} 18$ for $50 \mathrm{~min}\left(37^{\circ} \mathrm{C}\right)$. Unbound cells were washed free and adherent cells were quantitated as described previously (22). Bars = mean \pm SD of adherence normalized with respect to binding in the absence of antibody $(100 \%)$; one of three experiments.

\section{RESULTS}

\section{Antibody Inhibition of CD11b/CD18 Binding to ICAM-1}

To characterize the ability of antibodies to inhibit adhesion, the binding of ICAM-1-transfected L cells to purified $\mathrm{CD} 1 \mathrm{lb} / \mathrm{CD} 18$ was assessed (Fig. 1). R6.5 binds to the immunoglobulin superfamily (IgSF) domain 2 of ICAM-1 $(21,22)$, has been previously characterized to inhibit both CD1 la and CD11b/CD18-ICAM-1 binding (12), and blocked adhesion in this assay by $>75 \%$. Two newly generated antibodies, CBRICl/7 and CBRIC1/11, appear to bind to IgSF domain 3 of ICAM-1. Both CBRIC1/7 and CBRIC1/11 recognized the ICAM-1 protein containing all five domains (GPI-ICAM-1) but not the ICAM-1 mutant lacking the $\mathrm{CD} / \mathrm{lb} / \mathrm{CD} 18$-binding site (domain 3 of ICAM-1). These two mAbs inhibited adhesion to purified CD $11 \mathrm{~b} / \mathrm{CD} 18$ by $>75 \%$. In contrast, a third newly generated antibody, CBRICl/12, which also appears to bind to domain 3, did not inhibit adhesion. Since CBRIC1/12 binding to ICAM-1-expressing cells was comparable to that of CBRIC1/7 and CBRICl/ll (not shown), it served as a noninhibitory binding control for the domain 3 of ICAM-1. An additional control, RR1/l mAb, has 
been previously shown to inhibit CD1 la/CDl8but not $\mathrm{CD} / \mathrm{lb} / \mathrm{CD} 18$-mediated binding to ICAM-1 and maps to domain $1(21,36)$. Table 1 summarizes the inhibitory effects of the various anti-ICAM-1 mAbs on ICAM-1-mediated adhesive interactions with $\mathrm{CD} 1 \mathrm{lb} / \mathrm{CD} 18$ and CDlla/ CD 18.

\section{IFN $\gamma$ Induction of ICAM-1 Expression on T84 Cells}

ICAM-1 expression could not be detected by surface ELISA on unstimulated T84 cells (Fig. 2). In contrast, time- $\left(t_{1 / 2} \sim 30 \mathrm{hr}\right)$ (Fig. $\left.2 \mathrm{~A}\right)$ and concentration-dependent $\left(\mathrm{ED}_{50} \sim 30 \mathrm{U} / \mathrm{ml}\right)$ (Fig. $2 \mathrm{~B}$ ) expression of ICAM-1 was induced by IFN $\gamma$ preexposure. Binding of the various ICAM-1 antibodies to the surface of T84 monolayers was analyzed and compared by antibody dilution. While there was no detectable surface labeling in unstimulated monolayers, all ICAM-l mAbs bound to IFN $\gamma$-pretreated $(1000 \mathrm{U} / \mathrm{ml}, 48 \mathrm{hr}$ ) monolayers in a concentration-dependent manner with saturation at a concentration of 10 $\mu \mathrm{g} / \mathrm{ml}$ or less (Data not shown).

Since T84 cells assume a polarized phenotype on permeable supports, and polarized epithelia exhibit biochemically distinct apical and basolateral membrane domains, we examined whether ICAM-1 expression was domain restricted. Immunoprecipitation studies were performed on T84 monolayers that were selectively biotinylated on the apical or basolateral surface (Fig. 3). We and others have used selective cell surface labeling to successfully label apical and basolateral epithelial membrane proteins on cells cultured on permeable supports (47-51). As shown in Fig. 3, ICAM-1 was not expressed on either apical or basolateral surfaces in the basal state. In contrast, treatment with IFN $\gamma$ resulted in expression of ICAM-1 restricted to the apical domain (Fig. 3, (+) IFN, Lane A). In data not shown, strong labeling of a basolaterally restricted adhesive protein, $\beta 1$ integrin, was observed in immunoprecipitations with basolaterally biotinylated T84 cells.

Apical domain restricted expression of ICAM- 1 in fully polarized cells was confirmed by confocal microscopy localization (Fig. 4). En face images in the plane of the apical membrane revealed multifocal staining for ICAM-l in IFN $\gamma$ exposed but not in untreated cells (Fig. $4 \mathrm{~A}$ and B). In Pancl C of Fig. 4, reconstructed images confirmed that IFN $\gamma$ induced expression was limited to the apical membrane. No labeling was
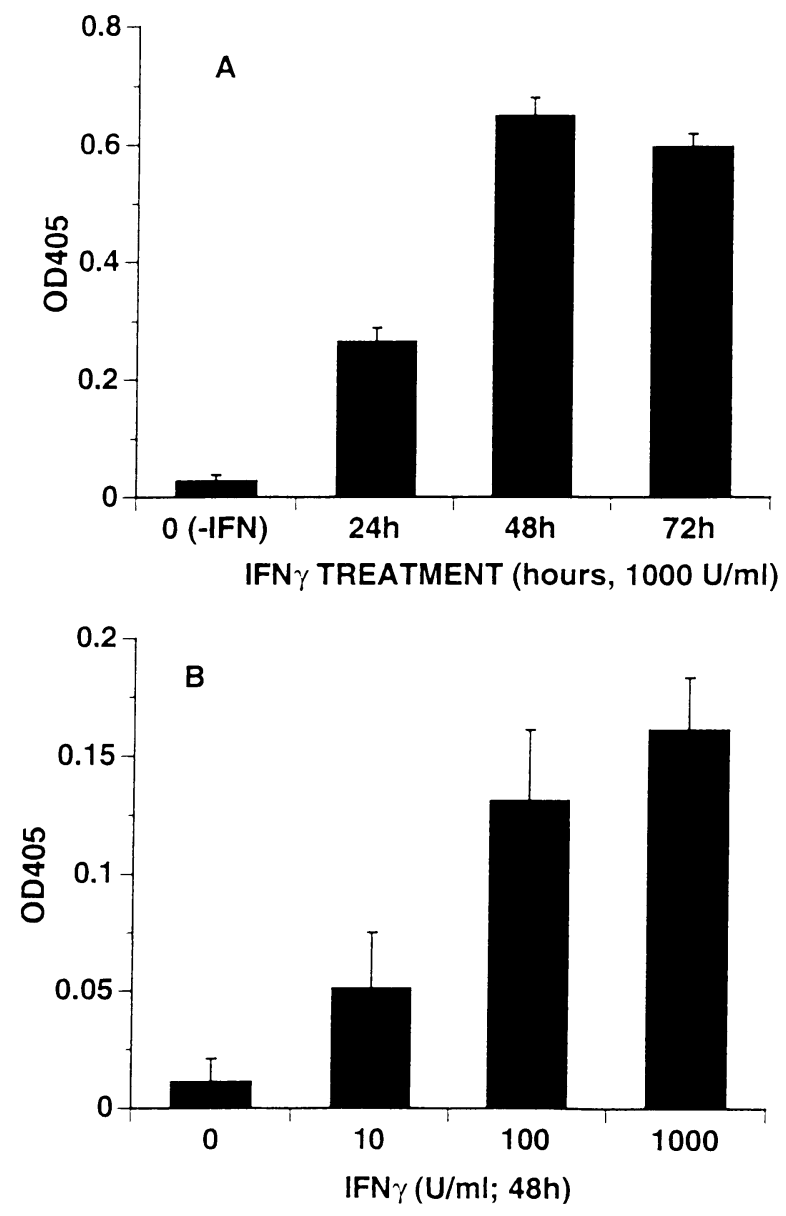

FIG. 2. Time course and concentration dependence of IF $\mathbf{\gamma}$-induced cell surface ICAM-1 expression on T84 cells

(A) As described in Materials and Methods, T84 cells cultured at 3/4 confluent density on 96-well tissue culture plates were exposed to IFN $\gamma(1000 \mathrm{U} / \mathrm{ml})$ for the times indicated and subsequently assayed for surface ICAM- 1 expression using mAb R6.5 by enzyme-linked immunosorbent assay (ELISA). (B) T84 cells similarly prepared were exposed to IFN $\gamma$ for 48 hr at the concentrations indicated and subsequently assayed for surface ICAM-1 by ELISA as in Panel A. Color was developed and quantitated at OD 405 using a microtiter plate reader as described in Materials and Methods. Optical density at $405 \mathrm{~nm}$ represents antibody-treated well values after subtraction of the values from wells treated with irrelevant nonbinding antibody control. Each value represents the mean \pm SD of four individual monolayers.

observed in unstimulated control T84 cells (Fig. 4D). Of interest was the lack of detectable ICAM- 1 expression on the basolateral surface of T84 monolayers (Fig. 4C). Such staining patterns were identical for T84 cell monolayers cultured in a standard or an inverted fashion. As controls for basolateral staining, Panels E and F of Fig. 4 


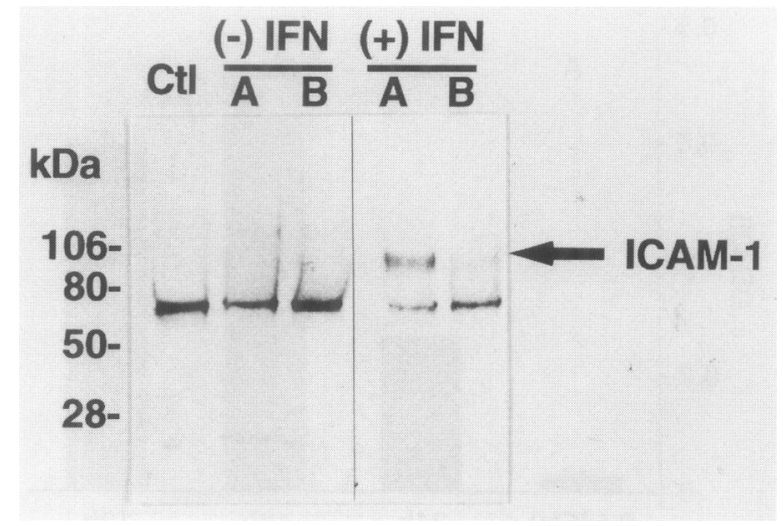

FIG. 3. Immunoprecipitation of ICAM-1 from confluent T84 monolayers following selective cell surface labeling (apical or basolateral biotinylation)

T84 monolayers cultured to confluency on $5-\mathrm{cm}^{2}$ permeable supports were cooled to $4^{\circ} \mathrm{C}$ and selectively labeled on the apical (Lanes A) or basolateral surface (Lanes B) with biotin followed by immunoprecipitation of ICAM-1 using mAb R6.5 as described in Materials and Methods. Immunoprecipitates were subjected to SDS-PAGE on $5-16 \%$ polyacrylamide gradient gels followed by Western blotting, incubation with streptavidin-peroxidase, and development by enhanced chemiluminescence. The immunoprecipitates of control, unstimulated monolayers ([-] IFN) were compared with those of monolayers maximally stimulated with IFN $\gamma([+]$ IFN). As can be seen, there is no ICAM-1 in the apically (A) or basolaterally labeled (B) unstimulated monolayers ([-] IFN). However, following IFN $\gamma$ stimulation $(1000 \mathrm{U} / \mathrm{ml}, 48 \mathrm{hr})$ there is the appearance of $a \sim 100 \mathrm{kD}$ ICAM-1 band in the apically labeled (A) but not the basolaterally labeled (B) lanes ([+] IFN). Ctl, control immunoprecipitation with normal mouse IgG; this lane shows a nonspecific, prominent $70-\mathrm{kD}$ band which is also observed in the ICAM-1 lanes.

show the confocal images of a basolaterally restricted protein, $\beta 1$ integrin $(46,52)$, which is observed as lateral cell membrane labeling. These data suggest that ICAM-1 is not expressed on the basolateral domain with which PMN interact during transepithelial migration.

\section{Inflammation-Elicited Surface Expression of ICAM-1 in Natural Intestinal Mucosa}

Since IFN $\gamma$ is a dominant cytokine in intestinal mucosa in states of intestinal inflammation (19), we examined inflamed intestinal mucosa by ICAM-1 immunostaining in order to determine whether ICAM-1 was similarly focally expressed and, if so, whether it was apically restricted. As shown in Panels G and I of Fig. 4, human crypt intestinal epithelia from inflamed mucosa also expressed ICAM-1 focally in an apically restricted manner. The localized staining in the crypt is consistent with T84 phenotype which displays functional characteristics of crypt, but not surface, intestinal epithelial cells. Also consistent with our findings using T84 cells (see above) and with other reports $(28,53,54)$, no detectable ICAM-1 expression was observed on control, noninflamed mucosa (data not shown).

\section{The Role of ICAM-1 in Neutrophil Transepithelial Migration}

APICAL-TO-BASOLATERAL MIGRATION OF PMN BECOMES ICAM-1 DEPENDENT FOLLOWING IFN $\gamma$ ACTIVATION. While it has been previously shown that PMN transepithelial migration is dependent on the neutrophil $\beta 2$ integrin $C D 11 b / C D 18$, little is known about epithelial ligands for this integrin $(16,18)$. Since an important vascular ligand for CD 1 1b/CD18 is ICAM-1, we investigated the role of ICAM-1 in PMN-intestinal epithelial interactions using a panel of anti-ICAM-1 mAbs that block CD11b/CD18-ICAM-1 binding. As shown in Panel A of Figure 5, none of the anti-ICAM-1 antibodies tested affected $\mathrm{fMLP}$-driven, apicalto-basolaterally directed PMN migration across resting T84 monolayers. In addition, transmigration in the absence of antibody was indistinguishable from the binding antibody control (data not shown).

In contrast, Fig. 5B shows that such nonphysiologically directed, fMLP-driven PMN transepithelial migration was significantly inhibited by R6.5, CBRIC1/11, and CBRIC1/7 in IFN $\gamma$ pre-exposed (i.e., ICAM-1-expressing) monolayers: $(64.4 \pm 4.3 \%, 73.8 \pm 13 \%$, and $50 \pm$ $19 \%$ inhibition for R6.5, CBRIC1/7, and CBRIC 1/11; $p<0.01,0.02$, and 0.05, respectively). Antibodies known to block either ICAM-1LFA-1 interactions (RR1/1) or to recognize an ICAM-1 domain 3-dependent epitope but not to influence ICAM-1-CD 1 lb/CD 18 interactions (CBRIC1/12) did not influence PMN transmigration.

PMN MIGRATION IN THE PHYSIOLOGIC (BASOLATERAL-TOAPICAL DIRECTION) IS INDEPENDENT OF ICAM-1. PMN migration physiologically occurs in the basolateral-to-apical direction. In contrast to apicalto-basolaterally directed migration, none of the antibodies inhibited physiologically directed mi- 
FIG. 4. Localization of ICAM-1 on T84 monolayers and natural human colonic epithelium by immunofluorescence

(A-F) T84 monolayers cultured on permeable supports were stimulated with IFN $\gamma(1000 \mathrm{U} / \mathrm{ml}, 48 \mathrm{hr})$, fixed with paraformaldehyde, permeabilized with Triton X-100, followed by labeling with primary antibody as described in Materials and Methods. Primary antibodies included anti-ICAM-1 (R6.5), control normal mouse IgG, and anti- $\beta 1$ integrin, an epithelial subjunctional adhesion molecule as a basolateral binding control (52). Shown are $x-y$ (en face) and $\mathrm{x}-\mathrm{z}$ computer reconstructed confocal fluorescence micrographs. (A and B) the $x-y$ (en face) immunofluorescence on the apical surface after staining for ICAM-1 on IFN $\gamma$ stimulated and control, unstimulated T84 monolayers, respectively. (C and D) the $\mathrm{X}-\mathrm{z}$ reconstructed immunofluorescence staining pattern for ICAM-1 following IFN $\gamma$ stimulation (C) or in the absence of IFN $\gamma$ stimulation (D). (E and F) As controls for basolateral labeling, the immunofluorescence staining patterns for $\beta 1$ integrin

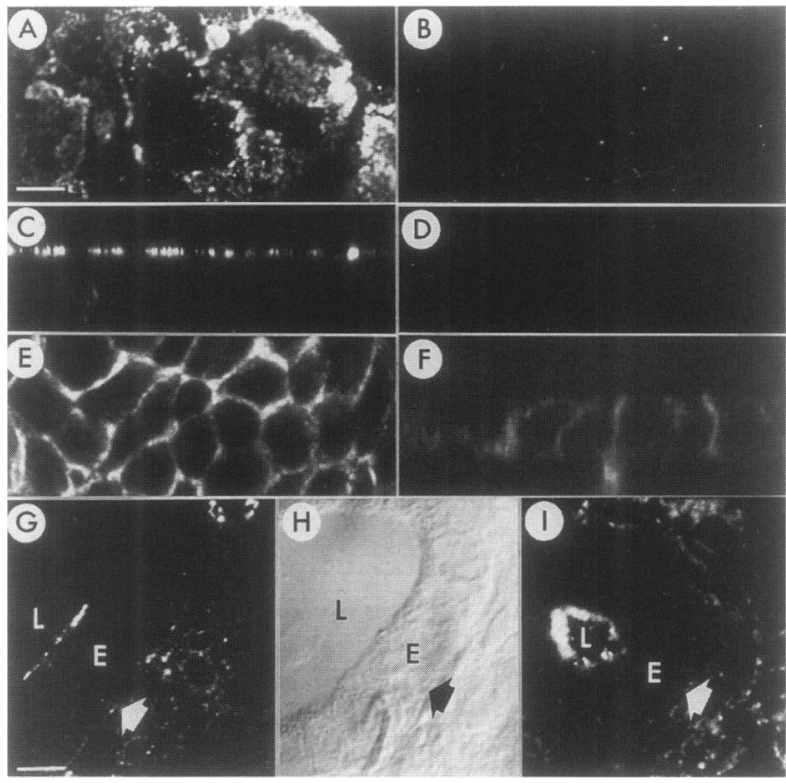
in the mid-zone $(x-y)$ of the monolayer and as an $\mathrm{X}-\mathrm{z}$ reconstructed image, respectively. As can be seen in Panel $\mathrm{B}$, there is no detectable ICAM-1 immunofluorescence in the absence of IFN $\gamma$ stimulation. However, there is bright apical ICAM-1 immunofluorescence after IFN $\gamma$ stimulation ( $\mathrm{A}$ and $\mathrm{C}$ ). Treatment of monolayers with normal mouse IgG (not shown) resulted in no detectable immunofluorescence, identical to that shown in Panel D. (G-I) Three-micron-thick frozen sections of human colonic epithelium involved with active inflammatory bowel disease. Sections were air dried, fixed with paraformaldehyde, and fluorescently labeled for ICAM-1 (R6.5, $3 \mu \mathrm{g} / \mathrm{ml})$. ( $\mathrm{G}$ and I) The ICAM-1 staining in active Crohn's disease with focal staining of the apical membrane and sub-epithelial inflammatory cells (to the right of the closed arrows): L, lumen; E, epithelium; closed arrow, the basal pole of the epithelium which abuts the basement membrane. (H) For orientation, the Nomarski image corresponding to that shown in Panel G. In data not shown, there was no significant ICAM-1 staining of epithelium in noninflamed colon sections or with irrelevant IgG. Scale bars in Panels $A$ and $G=20 \mu$.

gration, irrespective of IFN $\gamma$ pretreatment (W6/32 versus RR1/1, R6.5, CBRICl/7, CBRICl/ 11, CBRIC1/12; NS; Fig. 6). These results suggest that the morphologically and biochemically defined restricted expression of ICAM-1 to the apical membrane in IFN $\gamma$ exposed cells (and similarly imaged in inflamed colonic epithelia) precludes involvement of ICAM-1-CDIlb/ CD 18-mediated adhesive interactions in physiologically directed migration.

\section{The Role of ICAM-1 in Intestinal Epithelial Cell Adhesion to Purified CD11b/CD18}

T84 MONOLAYERS. The dependence of physiologically directed PMN transmigration on $\mathrm{CDIlb} /$ CD18 (16), with the apparent independence of PMN transmigration on expression of ICAM-1, suggested that $C D 11 \mathrm{~b} / \mathrm{CD} 18$-mediated binding of PMN to T84 cells involves ligands other than ICAM-1. To test this hypothesis, we next examined whether suspended T84 cells bound to pu- rified, surface immobilized, CD11b/CD 18 and, if so, whether such interactions occurred independently of ICAM-1. We first confirmed that surface ICAM-1 epitopes remained intact in suspended epithelial cells preactivated with IFN $\gamma$. Aliquots of approximately $1 \times 10^{7} \mathrm{~T} 84$ cells harvested by standard methods were washed and incubated with $10 \mu \mathrm{g} / \mathrm{ml}$ anti-ICAM-1 or control IgG for $2 \mathrm{hr}\left(4^{\circ} \mathrm{C}\right)$ followed by washing and incubation with peroxidase-conjugated secondary antibody. After washing the cell pellets, color was developed and the supernatants assayed using a microtiter plate reader as described in Materials and Methods. Control, unstimulated T84 cells were compared with T84 cells stimulated with IFN $\gamma$. Trypsin-insensitive surface ICAM-1 (R6.5) was readily detectable after IFN $\gamma$ stimulation ( 0.4 versus 0.6 and 2.27 OD units for control IgG versus unstimulated and IFN $\gamma$-stimulated T84 cells, respectively).

The effects of anti-ICAM-1 mAbs on adhesion of suspended T84 cells ( \pm IFN $\gamma$ preactivation) to immobilized $\mathrm{CD} 1 \mathrm{lb} / \mathrm{CD} 18$ were next as- 
FIG. 5. Effect of anti-ICAM-1 mAbs on apicalto-basolaterally directed PMN transepithelial migration

Transmigration assays were performed in the apicalto-basolateral direction on both untreated (A) and IFN $\gamma$-pretreated $(1000 \mathrm{U} / \mathrm{ml}, 48 \mathrm{hr}$; B) T84 monolayers cultured on $0.33-\mathrm{cm}^{2}$ permeable supports. As described in Materials and Methods, saturating concentrations of the antibodies $(10 \mu \mathrm{g} / \mathrm{ml})$ indicated were added to the apical side of confluent T84 monolayers and preincubated for $20 \mathrm{~min}\left(20^{\circ} \mathrm{C}\right)$ followed by addition of $1 \times 10^{6} \mathrm{PMN}$. The monolayers were transferred to 24-well tissue culture wells, each containing $1 \mathrm{ml}$ of $1 \mu \mathrm{M}$ fMLP in HBSS to initiate PMN transmigration which was allowed to proceed for $110 \mathrm{~min}\left(37^{\circ} \mathrm{C}\right)$. PMN which had transmigrated to the opposite reservoir or PMN within monolayers were quantitated by myeloperoxidase assay as described in Materials and Methods. Transmigration is normalized with respect to a control binding antibody, anti-MHC I W6/32 and expressed as a percentage of control. As can be seen in Panel A, none of the anti-ICAM-1 antibodies had any effect on transmigration in the control unstimulated monolayers. However, as shown in Panel B, following IFN $\gamma$ stimulation mAbs R6.5, CBRIC1/7, and CBRIC 1/1 1 significantly inhibited $(>60 \%)$ transmigration. In data not shown, anti-CDl lb (44a) but not antiCD1 la (TS1/22) markedly inhibited transmigration in such assays as previously reported $(16,18)$. Data represents the mean \pm SD of four monolayers for each condition; onc of three experiments.

sessed (Fig. 7). Although anti-CD $11 \mathrm{~b} / \mathrm{CD} 18 \mathrm{mAb}$ inhibited T84 cell binding by more than $90 \%$ (56.4 \pm 6.9 versus $2.4 \pm 0.4 \%$ adhesion for antibody control versus anti-CDllb/CDI8; $p<$ 0.01 ), none of the anti-ICAM-1 antibodies influenced T84 cell-CDllb/CDl 8 adhesive interactions, even when epithelial cells were pretreated with IFN $\gamma$ (Fig. 7A).

Since transepithelial migration of PMN has been shown to be CD11b/CD18 dependent and CDlla/CD 8 independent, it is likely that T84 cells selectively adhere to the CD11b/CD18 integrin. We thus tested this hypothesis using immobilized CDl1b/CDI8 or CDlla/CDl8. T84 cells preferentially adhered to purified CD1 1b/CD18 but not CD1 la/CD18 (61 $\pm 5 \%$ of applied cells adhered to Mac-1, while $5 \pm 3.3 \%$ adhered to LFA-1; $p<0.01$ ) (Fig. 7B). No significant adhesion to BSA alone was observed. Moreover, T84
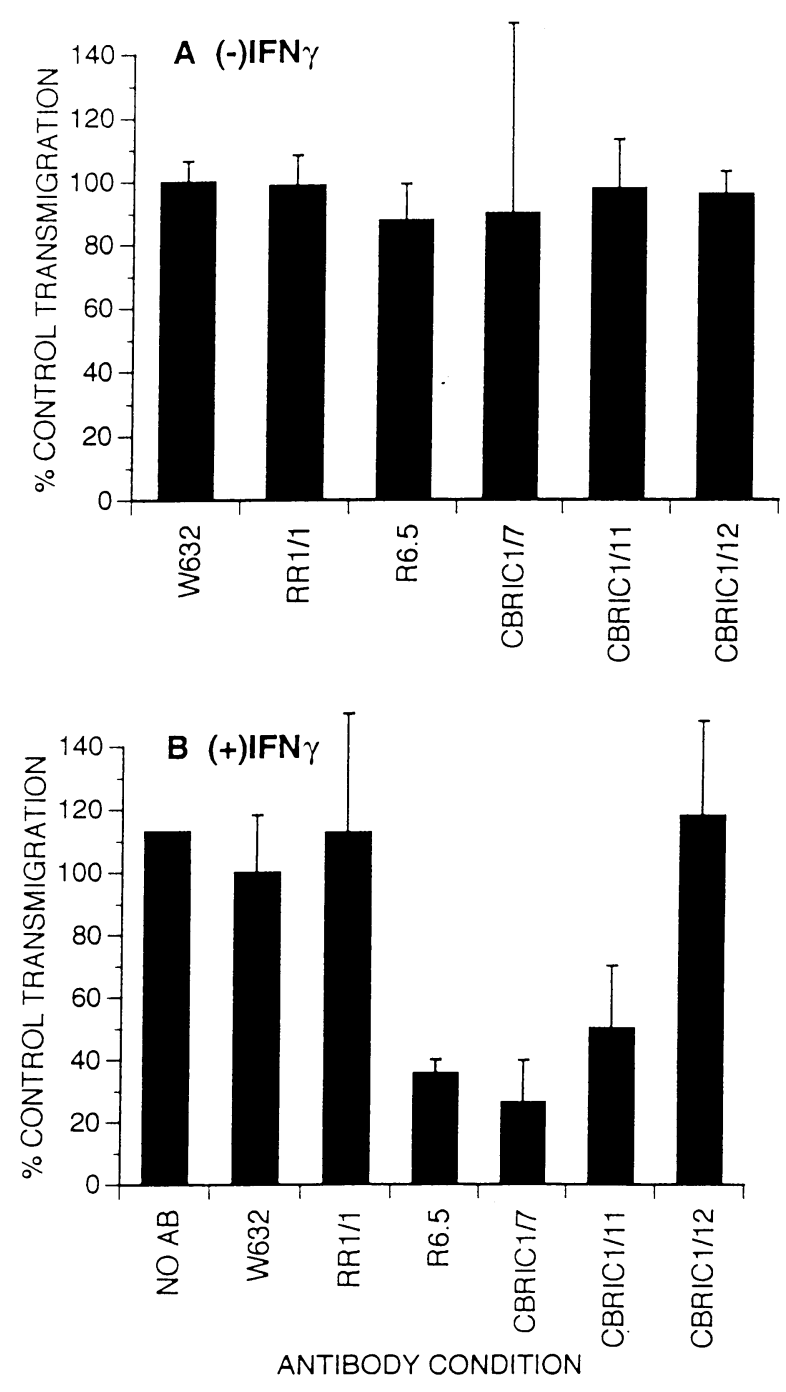

cells adhered to purified CD $1 \mathrm{lb} / \mathrm{CD} 18$ in a specific manner. Pretreatment of the CDIlb/CDI8coated plastic with inhibitory mAb to CDllb (CBRM1/29 or 44a $[33,41]$ ) completely inhibited T84 cell binding to CDllb/CD18 but had no effect on the small amount of observed binding to CD l la/CDI8 $(51 \pm 2$ cells adherent to Mac- 1 reduced to $0 \pm 1$ cell after anti-CD $1 \mathrm{lb}$ treatment versus $6.4 \pm 1.1$ cells adherent to CD 11 a/CD 18 before anti-CD $1 \mathrm{lb}$ and $7.6 \pm 2.1$ adherent after incubation with anti-CDl lb) (Fig. 7C).

CDIIb/CD18-MEDIATED, ICAM-I-INDEPENDENT ADHERENCE OF NATURAL HUMAN COLONOCYTES. The adhesion results using T84 cells above imply that intestinal epithelial cells adhere avidly to CD $1 \mathrm{lb} /$ CD 18 and do so, even in the IFN $\gamma$ stimulated state, by an ICAM-1-independent mechanism. To determine whether such observations were 

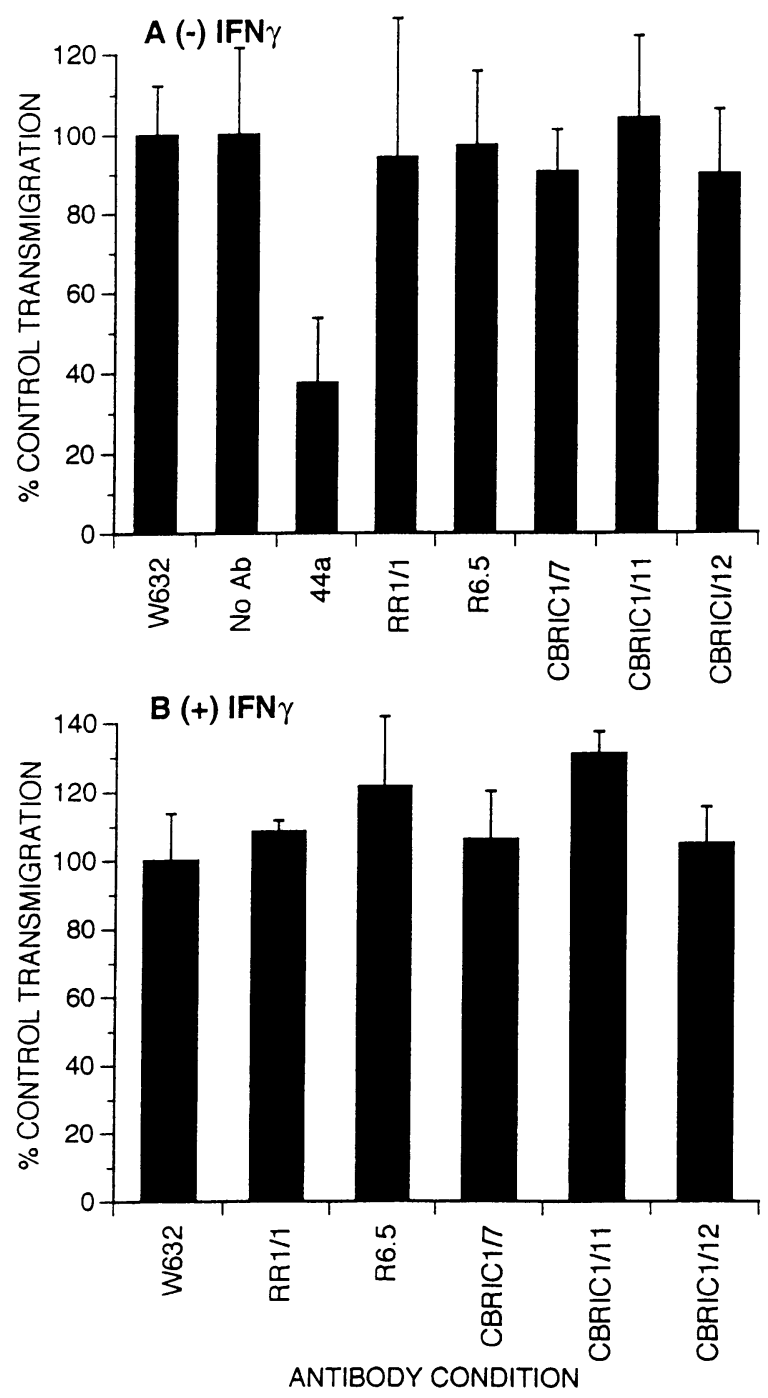

FIG. 6. Effect of anti-ICAM-1 mAbs on physiologically directed (basolateral-to-apical) PMN transepithelial migration

Transmigration assays were performed as in Fig. 6 except that inverted T84 monolayers were used and antibodies were applied to both apical and basolateral surfaces. As described in Materials and Methods, transmigration assays with such inverted monolayers allow gravitational settling of PMN onto the filter and subsequently, contact with the basolateral aspect of the monolayers prior to initiation of migration. Transmigration is normalized as a percentage of transmigration in the presence of the noninhibitory control antibody W6/32. As can be seen, there is no inhibitory effect of any of the ICAM-1 antibodies in unstimulated (A) or IFN $\gamma$-activated (B) monolayers. In addition, transmigration in the absence of antibody (no Ab; A) was not statistically different than that in the presence of W6/32. In data not shown, anti-CD 1 lb (44a) but not anti-CD1 la (TS1/22) markedly inhibits $(>65 \%)$ transmigration in such assays, as previously reported $(16,18)$. Data represents the mean $\pm \mathrm{SD}$ of four monolayers for each condition; one of three experiments.
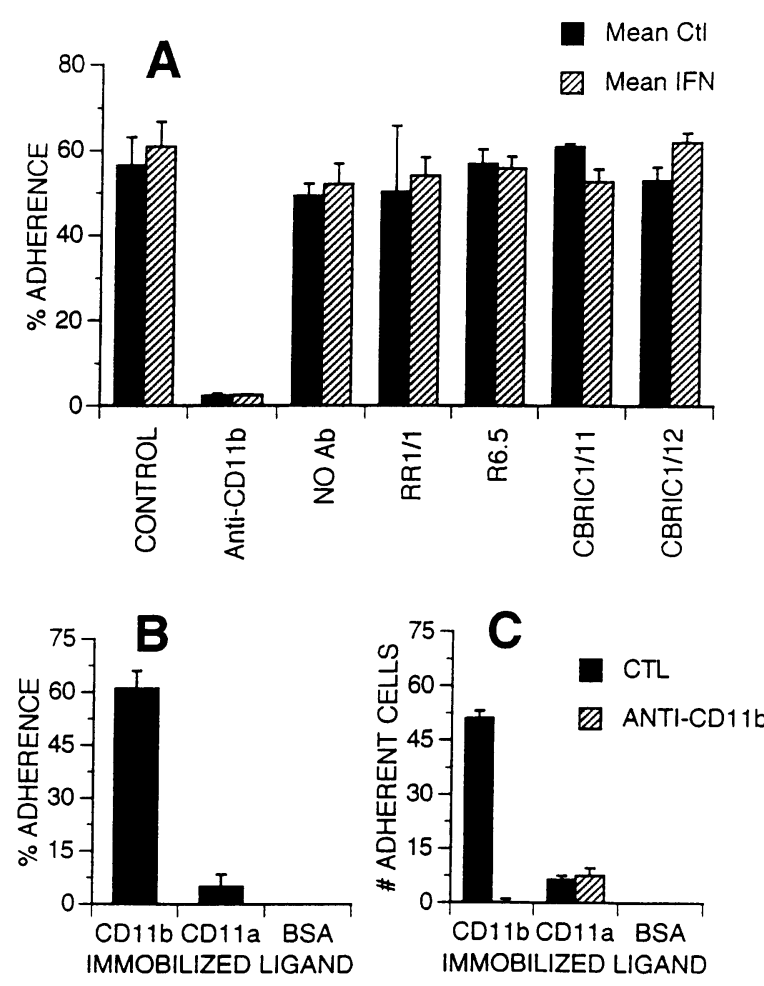

FIG. 7. ICAM-1-independent adherence of T84 cells to purified $C D 11$ b/CD18.

Suspensions of BCECF-AM-labeled T84 cells $(\sim 8 \times$ $10^{6} / \mathrm{ml}$ ) were preincubated with saturating concentrations of the antibodies shown followed by adhesion to purified CD11b/CD18 in 96-well tissue culture plates as described in Materials and Methods. (A) Percentage of applied cells adherent to CD11b/ CD18 after various antibody treatments is shown. Adhesion of control unstimulated T84 cells was compared with T84 monolayers stimulated with IFN $\gamma$. As an antibody control, adhesion in the presence of a noninhibitory anti-CDI lb antibody, OKMl, was used. As a functionally inhibitory antibody to CDl lb, mAb 44a was used by pretreating the $\mathrm{CD} 1 \mathrm{lb} / \mathrm{CD} 18$ coated wells for $30 \mathrm{~min}$ at $10 \mu \mathrm{g} /$ ml. (B) Adhesion of unstimulated T84 cells to purified $\mathrm{CDl} 1 \mathrm{~b} / \mathrm{CD} 18$ is compared with adhesion to CD1 la/CD18 and bovine serum albumin (BSA). (C) The effect of saturating concentrations of functionally inhibitory anti-CD l lb antibody (44a) on unstimulated $\mathrm{T} 84$ cell adhesion to CD $1 \mathrm{lb} / \mathrm{CD} 18$, CD1la/CD18, and BSA is shown. Adherent T84 cells (nonlabeled) within a defined area were quantitated by microscopy as described previously (14). Values representative of one of two experiments showing the mean \pm SD of quadruplicate determinations.

physiologically relevant, we studied adherence of natural intestinal epithelial cells to immobilized $C D 11 b / C D 18$. For these studies, epithelial cells were obtained from inflamed mucosa to bias in favor of detecting potential ICAM-1-mediated interactions with $\mathrm{CDI} / \mathrm{b} / \mathrm{CD} 18$. Adhesion of 


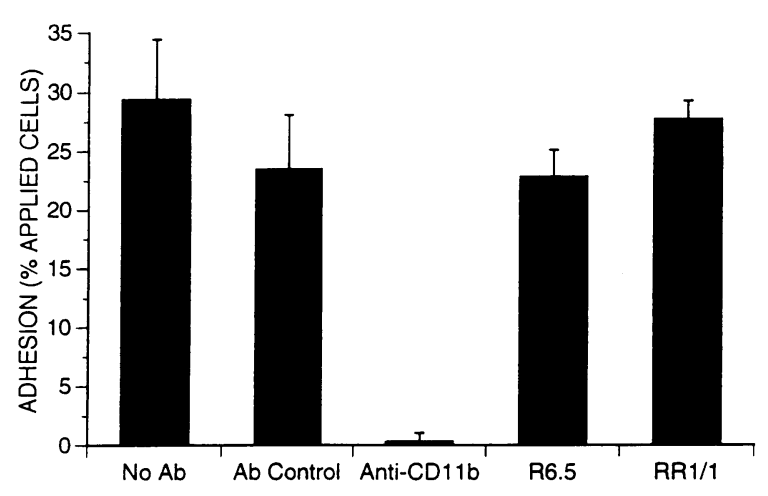

FIG. 8. ICAM-1-independent adherence of natural human colonocytes to purified CD11b/ CD18

Natural human colonocytes obtained from a surgical resection specimen of a patient with severe inflammatory bowel disease were labeled and used in adhesion assays with purified CD1 lb/CD18 as described in Fig. 7 and in Materials and Methods. As described in the previous figure, the negative antibody control ( $\mathrm{Ab}$ Control) represents adhesion after treatment of wells with OKMl. As a functionally inhibitory antibody to CD11b, mAb CBRM1/29 was used (Anti-CD1lb). Pretreatment of T84 cells with saturating concentrations of functionally inhibitory anti-ICAM-1 antibody R6.5 had no effect on the adhesion to $\mathrm{CD} 1 \mathrm{lb} / \mathrm{CD} 18$. Data represent the mean \pm $\mathrm{SD}$ of quadruplicate determinations.

colonocytes was reduced from $23.5 \pm 4.6 \%$ (for $\mathrm{Ab}$ control OKM1) to $0.3 \pm 0.7 \%$ after incubation with a functionally blocking mAb to CDI lb (Fig. 8). However, pretreatment of the colonocytes with anti-ICAM-1 mAbs failed to inhibit adhesion $(27.7 \pm 1.6 \%$ and $22.8 \pm 2.3 \%$ versus $23.5 \pm 4.6 \%$ adherence for RRl/l and R6.5 versus OKM1, respectively; NS) (Fig. 8). Additional studies were performed on natural human colonocytes obtained from uninflamed colon with indistinguishable results (data not shown). Such results indicate that normal and inflamed natural human intestinal epithelial cells, like T84 cells, can adhere to CD 1 lb/CD18 in an ICAM-1independent fashion.

\section{DISCUSSION}

These studies identify several aspects of human intestinal epithelial ICAM-1 expression potentially relevant to the biology of transepithelial migration of PMN. First, ICAM-1 is either not expressed or expressed at exceedingly low levels on the surface of resting T84 cells and intestinal epithelial cells from the uninflamed human colon. Second, when ICAM-1 surface expression is induced in vitro by IFN $\gamma$ exposure or in vivo by intestinal inflammation, it is exclusively restricted to the apical domain. Lastly, it is probable that ICAM-1 does not serve as an epithelial counterreceptor for PMN during basolateral-toapical (i.e., physiologically directed) transepithelial migration because of its apically restricted expression. These findings provide yet another contrast to transendothelial migration of neutrophils, in which ICAM-1 is positioned to function as a ligand for $C D 11 \mathrm{~b} / \mathrm{CD} 18$, since $\mathrm{PMN}$ first encounter ICAM-1 on the lumenal surface of blood vessels before migrating from the microvasculature.

ICAM-1 has been reported to be expressed in various epithelia in response to cytokines. Thus, epithelial ICAM-1 expression has implicitly been suggested to play a crucial role in leukocyteepithelial adhesive interactions (23-26,29,55). For example, ICAM-1 is expressed on (i) renal tubular epithelia during allograft rejection $(56,57)$; (ii) alveolar and bronchial epithelial cells, an effect increased in asthmatics and following infection, ozone injury, or inflammatory diseases $(29,58-61)$; (iii) primary cultures of urothelia when exposed to LPS and urothelial cell lines $(55,62)$; (iv) intestinal epithelia of patients with ulcerative colitis and graft-versushost disease $(27,28)$; and (v) gastric epithelia in association with colonization by Helicobacter $p y$ lori (23).

However, most studies have not addressed the polarized nature of epithelia when localizing the ICAM-1 protein expression on a cellular level $(23,25,26,62)$. Additionally, where shown, surface polarity of ICAM-1 has been strictly defined by immunohistochemistry. Biochemical assays of polarity and analyses of functional consequences of polarized ICAM-1 expression have not been reported. In the mouse and rat lung, immunoelectron microscopic localization of ICAM-1 has revealed restricted expression to the alveolar type I cell apical membrane $(63,64)$, just as we report here for intestinal epithelia. Similar studies also reveal induction of apical ICAM-1 on alveolar type II epithelial cells as a consequence of pneumonia $(63,65)$. In two inflammatory intestinal disease states (ulcerative colitis and graftversus-host disease), evaluation of published figures stained by immunoperoxidase techniques for ICAM-1 appear to reveal focal ICAM-1 expression on the lumenal epithelial surface $(27,28)$, also in agreement with our results. 
A study of an intestinal epithelial cell line with a high level of basal ICAM-1 expression concluded that ICAM-1 served as a ligand for PMN during transepithelial migration (25). However, PMN were added to the apical compartment, and thus apical-to-basolaterally directed migration was analyzed in this study. PMN migration across urothelial cells cultured on permeable supports has also been studied and transmigration found to be inhibited by mAb to ICAM-1 (55). However, the best available models to date for studies of cultured urothelial cells are, unfortunately, restricted to cell lines that do not form uniform monolayers with highly restricted permeability (i.e., are not likely to form the polarized monolayers that characterize normal human urothelia). In the skin, a multilayered and geometrically contrasting epithelium, ICAM- 1 is also expressed after stimulation with IFN $\gamma$ or $\mathrm{TNF} \alpha(66)$ and may play a role in the inflammatory response at this site $(66-68)$. Thus, while the results of the current study may apply to polarized epithelial monolayers (gastrointestinal tract, respiratory tract, kidneys), different paradigms may apply to stratified (multilayered) epithelia such as skin.

Although the natural epithelial ligand(s) for $\mathrm{CD} 11 \mathrm{~b} / \mathrm{CD} 18$ have not been identified, their existence is strongly implied since T84 cells and natural colonic epithelial cells strongly adhere to purified $\mathrm{CD} 1 \mathrm{lb} / \mathrm{CD} 18$ even under conditions that strongly inhibit ICAM-1-dependent adhesion. However, if other epithelial ligand(s) for $\mathrm{CD} 1 \mathrm{lb} / \mathrm{CD} 18$ exist, it is possible that binding of such ligand(s) could substitute for ICAM-1-mediated binding. Candidate epithelial receptors for neutrophils and/or CD1 lb/CD18 include carbohydrate structures. PMN transepithelial migration is markedly inhibited by mannose 6-phosphate, glucose 6-phosphate, and complex carbohydrates such as fucoidin. However, such carbohydrate-induced effects do not appear to be secondary to inhibition of $\mathrm{E}$, $\mathrm{L}$, or $\mathrm{P}$ selectins (17). In addition, we have recently shown that heparan sulfate glycans can interact directly with CD 11 lb/CD 18 (69). Thus, carbohydrate-mediated adhesive interactions between neutrophils and epithelia are likely to be important.

Given the apparent apically restricted distribution of ICAM-1 on intestinal epithelium, it is worthwhile considering what physiological role such defined expression may subserve, especially given the distinct differences from endothelial ICAM-1 expression. In the lung, there may be a role for apically expressed ICAM-1 which could provide a tether for alveolar macrophages which normally reside in the air-filled alveolar space. While it is possible that lumenal ICAM-1 might be important in "docking" inflammatory cells in or near sites of inflammation, such cells do not normally reside in the gut lumen. However, receptor-mediated pathways for secreted PMN products are present on the apical membrane of intestinal epithelium. We have shown that activated PMN release 5'AMP which is converted to adenosine by an apical $5^{\prime}$ ectonucleotidase (CD72) $(5,6,70)$. Adenosine then binds to an apical $\mathrm{A} 2 \mathrm{~b}$ receptor resulting in electrogenic chloride secretion (8). Such PMN-induced chloride secretion is the basis of secretory diarrhea and might serve to rid the intestine of noxious agents. Thus, under conditions of active inflammation, induction of adhesive ligands such as ICAM- 1 on the lumenal epithelial surface might serve to preserve $\mathrm{PMN}$-apical membrane interactions which play key regulatory roles for epithelial transport events.

In addition, ICAM-1-based interactions between PMN and the apical intestinal epithelial membrane might serve a role in the clearance of pathogens from the surface of the intestinal mucosa. Salmonella typhimurium, for example, after binding to the apical membrane of intestinal epithelial cells, induces the basolateral release of IL- 8 and apical release of other undefined chemotactic factors that promote PMN transepithelial migration $(71,72)$. Under such conditions, apical ICAM-1 expression might serve as an adhesive ligand which retains PMN at the specific site of bacterial attachment to epithelia.

In summary, the data reported here indicate that ICAM-1 cannot serve as a counterreceptor for $\mathrm{CD} 1 \mathrm{lb} / \mathrm{CD} 18$ during PMN transepithelial migration as it normally occurs during inflamed states. Such observations strongly suggest the presence of a novel counterreceptor(s) for $\mathrm{CD} 1 \mathrm{lb} / \mathrm{CD} 18$ on epithelial basolateral membrane domains. These data also suggest that, in order to define a potential role for ICAM-1-mediated interactions between PMN and epithelia, it is necessary to focus on post-transmigration events in which PMN are positioned to interface with appropriate ICAM-1-expressing domains.

\section{ACKNOWLEDGMENTS}

This work was supported in part by a research grant from the Crohn's and Colitis Foundation of America and by National Institutes of Health 
Grants HL54229, CA31798, CA31799, DK47662, DK7662, DK35932, and DK33506. The authors thank Denice Carnes for excellent tissue culture support and Susan Carlson for assistance in preparing the figures.

\section{REFERENCES}

1. Kumar NB, Nostrant TT, Appleman HD. (1982) The histopathologic spectrum of acute self-limited colitis (acute infectious type colitis). Am. J. Surg. Pathol. 6: 523-529.

2. Yardley JH, Donowitz M. (1977) In: Yardley $\mathrm{JH}$, Morson BC, (eds). The Gastrointestinal Tract. Williams and Wilkins, Baltimore, p. 57.

3. Nash S, Stafford J, Madara JL. (1987) Effects of polymorphonuclear leukocyte transmigration on barrier function of cultured intestinal epithelial monolayers. J. Clin. Invest. 80: 1104-1113.

4. Nash S, Stafford J, Madara JL. (1988) The selective and superoxide-independent disruption of intestinal epithelial tight junctions during leukocyte transmigration. Lab. Invest. 59: 531-537.

5. Nash S, Parkos CA, Nusrat A, Delp C, Madara JL. (1991) In vitro model of intestinal crypt abcess: A novel neutrophil-derived secretagogue activity. J. Clin. Invest. 87: 1474-1477.

6. Madara JL, Patapoff TW, Gillece-Castro B, et al. (1993) $5^{\prime}$-AMP is the neutrophil-derived paracrine factor that elicits chloride secretion from T84 epithelial monolayers. J. Clin. Invest. 91: 2320-2325.

7. Parkos CA, Colgan SP, Delp C, Arnaout MA, Madara JL. (1992) Neutrophil migration across a cultured epithelial monolayer elicits a biphasic resistance response representing sequential effects on transcellular and paracellular pathways. J. Cell Biol. 117: 757-764.

8. Strohmeier GR, Reppert SM, Lencer WI, Madara JL. (1995) The A2b adenosine receptor mediates cAMP responses to adenosine receptor agonists in human intestinal epithelia. J. Biol. Chem. 270: 2387-2394.

9. Hawker PC, McKay JS, Turnberg LA. (1980) Electrolyte transport across colonic mucosa from patients with inflammatory bowel disease. Gastroenterology 79: 508-511.

10. Springer TA. (1994) Traffic signals for lymphocyte recirculation and leukocyte emigration: The multistep paradigm. Cell 76: 301314.

11. Parkos CA, Colgan S, Liang TW, et al. (1996)
CD47 mediates post-adhesive events required for neutrophil migration across polarized intestinal epithelia. J. Cell Biol. 132: 437450.

12. Smith CW, Marlin SD, Rothlein R, Toman C, Anderson DC. (1989) Cooperative interactions of LFA-1 and Mac-1 with intercellular adhesion molecule- 1 in facilitating adherence and transendothelial migration of human neutrophils in vitro. J. Clin. Invest. 83: 2008-2017.

13. Dustin ML, Sanders ME, Shaw S, Springer TA. (1987) Purified lymphocyte function-associated antigen 3 binds to CD2 and mediates $\mathrm{T}$ lymphocyte adhesion. J. Exp. Med. 165: 677-692.

14. Diamond MS, Staunton DE, de Fougerolles AR, et al. (1990) ICAM-1 (CD54): A counter-receptor for Mac-1 (CD11b/CD18). J. Cell Biol. 111: 3129-3139.

15. Smith CW, Rothlein $R$, Hughes $B J$, et al. (1988) Recognition of an endothelial determinant for CD18-dependent human neutrophil adherence and transendothelial migration. J. Clin. Invest. 82: 1746-1756.

16. Parkos CA, Delp C, Arnaout MA, Madara JL. (1991) Neutrophil migration across a cultured intestinal epithelium: Dependence on a CDIlb/CDI8-mediated event and enhanced efficiency in the physiologic direction. J. Clin. Invest. 88: 1605-1612.

17. Colgan SP, Parkos CA, McGuirk DK, et al. (1995) Receptors involved in carbohydrate binding modulate intestinal epithelial-neutrophil interactions. J. Biol. Chem. 270: 10531-10539.

18. Colgan SP, Parkos CA, Delp C, Arnaout MA, Madara JL. (1993) Neutrophil migration across cultured intestinal epithelial monolayers is modulated by epithelial exposure to IFN- $\gamma$ in a highly polarized fashion. $J$. Cell Biol. 120: 785-798.

19. Quiding $M$, Nordstrom I, Kilander A, et al. (1991) Intestinal immune responses in humans: Oral cholera vaccination induces strong intestinal antibody responses and interferon-gamma production and evokes local immunological memory. J. Clin. Invest. 88: $143-148$.

20. Yamamoto $M$, Fujihashi $K$, Beagley $K W$, McGhee JR, Kiyono H. (1993) Cytokine synthesis by intestinal intraepithelial lymphocytes: Both $\gamma / \delta \mathrm{T}$-cell receptor-positive and $\alpha / \beta$ T-cell receptor-positive T-cells in the $G_{1}$ 
phase of the cell cycle produce IFN- $\gamma$ and IL-5. J. Immunol. 150: 106-1 14.

21. Staunton DE, Dustin ML, Erickson HP, Springer TA. (1990) The arrangement of the immunoglobulin-like domains of ICAM-1 and the binding sites for LFA- 1 and rhinovirus [published errata appear in Cell 1990 Jun 15; 61: 1157 and 1991 Sep 20; 66: following 1311]. Cell 61: 243-254.

22. Diamond MS, Staunton DE, Marlin SD, Springer TA. (1991) Binding of the integrin Mac-1 (CD11b/CD18) to the third immunoglobulin-like domain of ICAM-1 (CD54) and its regulation by glycosylation. Cell 65: 961971.

23. Crowe SE, Alvarez L, Dytoc M, et al. (1995) Expression of interleukin 8 and CD54 by human gastric epithelium after Helicobacter pylori infection in vitro. Gastroenterology 108: 65-74.

24. Kelly CP, O'Keane JC, Orellana J, et al. (1992) Human colon cancer cells express ICAM-1 in vivo and support LFA-1-dependent lymphocyte adhesion in vitro. Am. J. Physiol. 263: G864-G870.

25. Kelly CP, Keates S, Siegenberg D, Linevsky JK, Pothoulakis C, Brady HR. (1994) IL-8 secretion and neutrophil activation by HT-29 colonic epithelial cells. Am. J. Physiol. Gastrointest. Liver Physiol. 30: G991-G997.

26. Kaiserlian D, Rigal D, Abello J, Revillard JP. (1991) Expression, function and regulation of the intercellular adhesion molecule-1 (ICAM-1) on human intestinal epithelial cell lines. Eur. J. Immunol. 21: 2415-2421.

27. Nakamura $S$, Ohtani $H$, Watanabe $Y$, et al. (1993) In situ expression of the cell adhesion molecules in inflammatory bowel disease: Evidence of immunologic activation of vascular endothelial cells. Lab. Invest. 69: 77-85.

28. Norton J, Sloane JP, al-Saffar N, Haskard DO. (1992) Expression of adhesion molecules in human intestinal graft-versus-host disease. Clin. Exp. Immunol. 87: 231-236.

29. Tosi MF, Stark JM, Hamedani A, Smith CW, Gruenert DC, Huang YT. (1992) Intercellular adhesion molecule-1 (ICAM-1)-dependent and ICAM-1-independent adhesive interactions between polymorphonuclear leukocytes and human airway epithelial cells infected with parainfluenza virus type 2 . J. Immunol. 149: 3345-3349.

30. Dharmsathaphorn K, Madara JL. (1990) Established intestinal cell lines as model sys- tems for electrolyte transport. Methods Enzymol. 192: 354-389.

31. Madara JL, Colgan SP, Nusrat A, Delp C, Parkos CA. (1992) A simple approach to measurement of electrical parameters of cultured epithelial monolayers: Use in assessing neutrophil epithelial interactions. J. Tiss. Cult. Meth. 14: 209-216.

32. Chan PY, Springer TA. (1992) Effect of lengthening lymphocyte function-associated antigen 3 on adhesion to CD2. Mol. Biol. Cell 3: 157-166.

33. Diamond MS, Garcia-Aguilar J, Bickford JK, Corbi AL, Springer TA. (1993) The I domain is a major recognition site on the leukocyte integrin Mac-1 (CD1 lb/CD18) for four distinct adhesion ligands. J. Cell Biol. 120: 10311043.

34. Weiser MM. (1973) Intestinal epithelial cell surface membrane glycoprotein synthesis. J. Biol. Chem. 248: 2536-2541.

35. Henson P, Oades ZG. (1975) Stimulation of human neutrophils by soluble and insoluble immunoglobulin aggregates. J. Clin. Invest. 56: 1053-1061.

36. Staunton DE, Merluzzi VJ, Rothlein R, Barton R, Marlin SD, Springer TA. (1989) A cell adhesion molecule, ICAM-1, is the major surface receptor for rhinoviruses. Cell 56: 849-853.

37. Rothlein R, Dustin ML, Marlin SD, Springer TA. (1986) A human intercellular adhesion molecule (ICAM-1) distinct from LFA-1. J. Immunol. 137: 1270-1274.

38. Barnstable CJ, Bodmer WF, Brown G, et al. (1978) Production of monoclonal antibodies to group A erythrocytes, HLA and other human cell surface antigens-new tools for genetic analysis. Cell 14: 9-20.

39. Sanchez-Madrid F, Krensky AM, Ware CF, et al. (1982) Three distinct antigens associated with human T-lymphocyte-mediated cytolysis: LFA-1, LFA-2 and LFA-3. Proc. Natl. Acad. Sci. U.S.A. 79: 7489-7493.

40. Wright SD, Rao PE, van Voorhis WC, et al. (1983) Identification of the C3bi receptor of human monocytes and macrophages by using monoclonal antibodies. Proc. Natl. Acad. Sci. U.S.A. 80: 5699-5703.

41. Todd RF, Nadler LM, Schlossman SF. (1981) Antigens on human monocyte identified by monoclonal antibodies. J. Immunol. 126: 1435-1442.

42. Stacker SA, Springer TA. (1991) Leukocyte integrin P150,95 (CD 1 1 C/CD 18) functions as 
an adhesion molecule binding to a counterreceptor on stimulated endothelium. J. Immunol. 146: 648-655.

43. Marlin SD, Springer TA. (1987) Purified intercellular adhesion molecule-1 (ICAM-1) is a ligand for lymphocyte function-associated antigen 1 (LFA-1). Cell 51: 813-819.

44. Klickstein LB, Springer TA. (1995) CD54 (ICAM-1) cluster report. In: Schlossman VSF, Boumsell L, Gilks W, et al. (eds). Leukocyte Typing. Oxford University Press, New York, pp. 1548-1550.

45. Dustin ML, Garcia-Aguilar J, Hibbs ML, et al. (1989) Structure and regulation of the leukocyte adhesion receptor LFA-1 and its counterreceptors, ICAM-1 and ICAM-2. Cold Spring Harb. Symp. Quant. Biol. 54: 753-765.

46. Parkos CA, Colgan SP, Bacarra AE, et al. (1995) Intestinal epithelia (T84) possess basolateral ligands for $\mathrm{CDIlb} / \mathrm{CD} 18$ mediated neutrophil adherence. Am. J. Physiol. 268: C472-C479.

47. Le Bivic A, Sambuy Y, Mostov K, RodriguezBoulan E. (1990) Vectorial targeting of an endogenous apical membrane sialoglycoprotein and uvomorulin in MDCK cells. J. Cell Biol. 110: 1533-1539.

48. Lencer WI, Moe S, Rufo PA, Madara JL. (1995) Transcytosis of cholera toxin subunits across model human intestinal epithelia. Proc. Natl. Acad. Sci. U.S.A. 92: 10094-10098.

49. Gottardi CJ, Dunbar LA, Caplan MJ. (1995) Biotinylation and assessment of membrane polarity: Caveats and methodological concerns. Am. J. Physiol. 268: F285-F295.

50. Lisanti MP, Le Bivic A, Saltiel AR, Rodriguez-Boulan E. (1990) Preferred apical distribution of glycosyl-phosphatidyinositol (GPI) anchored proteins: A highly conserved feature of the polarized epithelial cell phenotype. J. Membr. Biol. 113: 155-167.

51. Kaoutzani P, Parkos CA, Delp-Archer C, Madara JL. (1993) Isolation of plasma membrane fractions from the intestinal epithelial model T84. Am. J. Physiol. 264(Cell Physiol.) 33: C1327-C1335.

52. Quaranta V. (1990) Epithelial Integrins. Cell Differentiation and Development 32: 361-366.

53. Dustin ML, Rothlein R, Bhan AK, Dinarello CA, Springer TA. (1986) Induction by IL 1 and interferon-gamma: Tissue distribution, biochemistry, and function of a natural adherence molecule (ICAM-1). J. Immunol. 137: $245-254$.

54. Dippold W, Wittig B, Schwaeble W, Mayet
W, Meyer zum Buschenfelde KH. (1993) Expression of intercellular adhesion molecule 1 (ICAM-1, CD54) in colonic epithelial cells. Gut 34: 1593-1597.

55. Agace WW, Patarroyo $M$, Svensson $M$, Carlemalm E, Svanborg C. (1995) Escherichia coli induces transuroepithelial neutrophil migration by an intercellular adhesion molecule1-dependent mechanism. Infect. Immun. 63: 4054-4062.

56. Brockmeyer C, Ulbrecht $M$, Schendel DJ, et al. (1993) Distribution of cell adhesion molecules (ICAM-1, VCAM-1, ELAM-1) in renal tissue during allograft rejection. Transplantation 55: 610-615.

57. Chow J, Hartley RB, Jagger C, Dilly SA. (1992) ICAM-1 expression in renal disease. J. Clin. Pathol. 45: 880-884.

58. Hill PA, Lan HY, Nikolic-Paterson DJ, Atkins RC. (1994) Pulmonary expression of ICAM-1 and LFA-1 in experimental Goodpasture's syndrome. Am. J. Pathol. 145: 220-227.

59. Ibrahi L, Dominguez M, Yacoub M. (1993) Primary human adult lung epithelial cells in vitro: Response to interferon-gamma and cytomegalovirus. Immunology 79: 119-124.

60. Tosi MF, Hamedani A, Brosovich J, Alpert SE. (1994) ICAM-1-independent, CD18-dependent adhesion between neutrophils and human airway epithelial cells exposed in vitro to ozone. J. Immunol. 152: 1935-1942.

61. Wegner CD, Gundel RH, Reilly P, Haynes N, Letts LG, Rothlein R. (1990) Intercellular adhesion molecule-1 (ICAM-1) in the pathogenesis of asthma. Science 247: 456-459.

62. Elgavish A. (1993) Effects of Escherichia coli and E. coli lipopolysaccharides on the function of human ureteral epithelial cells cultured in serum-free medium. Infect. Immun. 61: 3304-3312.

63. Burns AR, Takei F, Doerschuk CM. (1994) Quantitation of ICAM-1 expression in mouse lung during pneumonia. J. Immunol. 153: 3189-3198.

64. Christensen PJ, Kim S, Simon RH, Toews GB, Paine RD. (1993) Differentiation-related expression of ICAM-1 by rat alveolar epithelial cells. Am. J. Respir. Cell Mol. Biol. 8: 9-15.

65. Kang BH, Crapo JD, Wegner C, Letts LG, Chang LY. (1993) Intercellular adhesion molecule-1 expression on the alveolar epithelium and its modification by hyperoxia. Am. J. Respir. Cell Mol. Biol. 9: 350-355.

66. Dustin ML, Singer KH, Tuck DT, Springer TA. (1988) Adhesion of $T$ lymphoblasts to 
epidermal keratinocytes is regulated by interferon gamma and is mediated by intercellular adhesion molecule 1 (ICAM-1). J. Exp. Med. 167: 1323-1340.

67. Vejlsgaard GL, Ralfkiaer E, Avnstorp C, Czajkowski M, Marlin SD, Rothlein R. (1989) Kinetics and characterization of intercellular adhesion molecule-1 (ICAM-1) expression on keratinocytes in various inflammatory skin lesions and malignant cutaneous lymphomas. J. Am. Acad. Dermatol. 20: 782-790.

68. Nickoloff BJ, Griffiths CE, Barker JN. (1990) The role of adhesion molecules, chemotactic factors, and cytokines in inflammatory and neoplastic skin disease-1990 update. $J$. Invest. Dermatol. 94: 151S-157S.

69. Diamond MS, Alon R, Parkos CA, Quinn MT, Springer TA. (1995) Heparin is an ad- hesive ligand for the leukocyte integrin Mac-1 (CD11b/CD18). J. Cell Biol. 130: 1473-1482.

70. Madara JL, Parkos CA, Colgan SP, et al. (1992) $\mathrm{Cl}^{-}$secretion in a model intestinal epithelium induced by a neutrophil-derived secretagogue. J. Clin. Invest. 89: 1938-1944.

71. McCormick BA, Colgan SP, Delp-Archer C, Miller SI, Madara JL. (1993) Salmonella typhimurium attachment to human intestinal epithelial monolayers: Transcellular signalling to subepithelial neutrophils. J. Cell Biol. 123: 895-907.

72. McCormick BA, Hofman PM, Kim J, Carnes DK, Miller SI, Madara JL. (1995) Surface attachment of Salmonella typhimurium to intestinal epithelia imprints the subepithelial matrix with gradients chemotactic for neutrophils. J. Cell Biol. 131: 1599-1608.

Contributed by R. Cotran on May 15, 1996. 